\title{
ecompós
}

ID: 2463

DOI: https://doi.org/10.30962/ec.2463

Recebido em: 08/04/2021

Aceito em: 01/11/2021

\section{$O$ presente como história: estéticas da elaboração no cinema brasileiro contemporâneo}

\section{Claudia Mesquita}

Universidade Federal de Minas Gerais, Belo Horizonte, Minas Gerais, Brasil

\section{Resumo}

Na trilha de Andreas Huyssen (2014), que identifica uma preocupação central com a memória na cultura contemporânea (resposta à confiança decrescente no futuro das sociedades ocidentais), o artigo busca examinar como o cinema brasileiro recente tem elaborado a experiência histórica. Para tanto, realiza um pequeno inventário, testando a reunião dos filmes em séries, de modo a indicar e caracterizar "figuras de elaboração histórica" recorrentes nesta filmografia. Em nosso mapeamento, destaca-se a aposta no "presente como história": sob a sombra de um "passado que não passa" ou desenhado como "avesso do futuro", o presente ganha centralidade em filmes que assumem a tarefa da rememoração crítica.

\section{Palavras-Chave}

Cinema brasileiro contemporâneo. Elaboração histórica. Rememoração crítica.

The present as history: aesthetics of elaboration in contemporary Brazilian cinema Abstract

Following Andreas Huyssen's path (2014), who pinpoints a pivotal concern with memory in contemporary culture, a response to Western societies' decreasing confidence in the future, the article seeks to examine how contemporary Brazilian cinema has been elaborating historical experience. To do so, we have created a small inventory, experimenting with the grouping of films in series, in order to indicate and characterize recurring "figures of historical elaboration" in such filmography. The emphasis on the "present as history" stands out in our mapping: under the shade of a "past that does not pass" or designed as "the reverse of the future" the present becomes the center of these films.

\section{Keywords}

Contemporary Brazilian Cinema. Memory. Historical Elaboration. 


\section{ecompós}

\section{El presente como historia: estéticas de la elaboración en el cine brasileño contemporáneo Resumen}

En la senda propuesta por Andreas Huyssen (2014), que identifica una preocupación central por la memoria en la cultura contemporânea, respuesta a la decreciente confianza en el futuro de las sociedades occidentales, el artículo busca examinar cómo el cine brasileño ha elaborado la experiencia histórica. Para esto, realizamos un pequeño inventario, probando la reunión de películas en series, de modo a indicar y caracterizar "figuras de elaboración histórica" recurrentes en la filmografia. En nuestro mapeo se destaca la apuesta en el "presente como historia": bajo la sombra de un "pasado que no pasa" o diseñado como "el revés del futuro", el presente adquiere centralidad en esas películas.

\section{Palabras claves}

Cine Brasileño Contemporáneo. Memoria. Elaboración Histórica.

\section{Introdução}

Em alguns de seus textos recentes (2002, 2014), Andreas Huyssen, historiador alemão da cultura, tem elaborado mutações na percepção do tempo histórico no Ocidente, afetada, em sua hipótese, pelos poderes globais. Dialogando com Reinhardt Koselleck, autor de Futuro passado (2006), Huyssen defende que, a partir dos anos 1990, sobretudo, entra em colapso o modelo moderno de historicidade: aquele que concebia o tempo como seta ascendente rumo ao futuro, e que tinha no progresso sua palavra-chave. Em resposta à confiança decrescente no futuro das sociedades ocidentais, teria ressurgido de maneira peculiar o passado: os futuros (antes tão presentes) que impulsionavam a cultura modernista teriam sido substituídos pela preocupação central com a memória. Viveríamos, na hipótese de Huyssen, a emergência de “culturas do passado-presente" (2014).

A “nostalgia de ruínas" (HUYSSEN, 2014) que marcaria, em sua leitura, a sensibilidade contemporânea, esconde a "saudade de uma era anterior, que ainda não tinha perdido o poder de imaginar outros futuros" (2014, p. 91). Enfraquecidas as energias utópicas da modernidade clássica, produções culturais contemporâneas cultivariam imagens de escombros da modernização: resíduos da era industrial, paisagens desoladas dos conglomerados socialistas desativados, e o interesse por traumas coletivos, histórias obscuras e apagadas, "não-lugares de 


\section{ecompós}

memória". ${ }^{1}$ O investimento no passado e a expansão da memória, sintomáticos de uma relação obliterada com o futuro, teriam se tornado mesmo, na hipótese de Huyssen, fenômenos transnacionais. Eles se associariam ao esfacelamento das identidades nacionais e à emergência de reivindicações de grupos específicos, produzindo "palimpsestos da memória" (2014, p. 183) que não reconhecem fronteiras (como no caso emblemático da globalização da memória do Holocausto).

Nesse contexto, interessa-nos indagar a experiência brasileira, no que apresenta de singular e nos modos como manifesta sintomas do fenômeno mais abrangente aqui brevemente descrito. Acreditamos que, no Brasil, a emergência de discursos memoriais não é apenas sintomática, mas politicamente urgente. "Mal começamos a testemunhar", nos diz Marcio Seligmann-Silva (2010, p. 14), referindo-se à importância do testemunho em sociedades em processo de redemocratização. Do passado colonial e escravocrata ao genocídio (ainda em curso) das populações negras e indígenas, passando pelo terrorismo de Estado durante a ditadura militar (1964-1985), a memória pública tem sido impedida no Brasil por "normas de recalque" (AB'SÁBER, 2013) e pelas amarras tenazes de "políticas do esquecimento" (SELIGMANN-SILVA, 2010, p. 14), como a Lei da Anistia (1979). E o que é mais decisivo, como nos lembra Ab'Sáber: "essa fantasmagoria imensa de nosso passado (...) não é massa morta de referências esquecidas": ela é "matéria viva", presente, "não ultrapassada, mesmo que modernizada" (2015, p. 102).

Acreditamos que o cinema e outros artefatos culturais podem desempenhar papel constitutivo na elaboração e transformação da memória pública, fazendo-se espaço de reflexão sobre o vivido e instrumento contra o negacionismo e o apagamento das memórias de violências passadas. Na trilha de Huyssen, interessa-nos, então, investigar como as formas fílmicas têm abrigado "a tarefa de assumir a responsabilidade pelo passado" (2014, p. 195), na contramão da consciência temporal da alta modernidade - que buscava, por sua vez, "garantir futuros

\footnotetext{
${ }^{1}$ Fazemos referência aos "lugares de memória" teorizados por Pierre Nora (1993), sítios nos quais, em momento de crise da transmissão, se "penduraria" a memória coletiva nacional. A expressão "não-lugares de memória" foi utilizada por Claude Lanzmann para sublinhar a diferença marcante dos espaços revisitados por sobreviventes do Holocausto em seu filme Shoah (1985): sítios arruinados, marcados pelo apagamento, pelo projeto nazista de não deixar rastros, por memórias traumáticas. A filmografia e toda a produção cultural em torno do Holocausto poderiam ser acionadas como exemplo da presença crescente do passado nos debates públicos ocidentais, identificada por Huyssen.
} 


\section{eccompós}

utópicos" (2014, p. 195). Gostaríamos ainda de examinar como as representações propostas pelo cinema têm disputado memórias e moldado "os processos de memória pública e de esquecimento" (HUYSSEN, 2014, p. 159) no Brasil.

Entendendo as formas fílmicas não apenas como sintomáticas (de seu momento de produção), mas como espaço de elaboração de experiências e formas históricas, propomos neste artigo uma primeira aproximação à problemática acima indicada, a partir do exame de obras contemporâneas (documentários, ficções e filmes híbridos) que não apenas enlaçam tempos, produzindo historicidade, ${ }^{2}$ como apresentam um contundente esforço de rememoração crítica do passado (entendido como força que age no presente). Em nosso percurso, vamos retomar análises individuais de algumas obras, mas buscando associá-las a outros filmes, de modo a conduzir um mapeamento. Para tanto, testamos a reunião dos filmes em séries, visando indicar e caracterizar "figuras de elaboração histórica" recorrentes na filmografia contemporânea assim como examinar suas variações a partir da aproximação entre obras. O propósito do artigo, assim, não é a análise em profundidade de uma ou de outra obra, mas o desenho, ainda inacabado, de um quadro mais abrangente, que mapeia linhas de força, potencialidades da produção contemporânea em seu trato com a memória pública.

Mesmo que privilegiando a produção dos anos 2000 em diante, faremos recuo a um filme paradigmático, que data de momento anterior, de modo a traçar as linhas do que entendemos como "estética da elaboração" e iluminar os modos singulares como essa abordagem se atualiza na produção contemporânea. Em nosso artigo, iremos transitar por Cabra marcado para morrer (Eduardo Coutinho, 1984), A cidade é uma só?, Branco sai, preto fica e Era uma vez Brasília (Adirley Queirós, 2012, 2014 e 2017), Recife frio e O som ao redor (Kleber Mendonça Filho, 2010 e 2012), Orestes (Rodrigo Siqueira, 2015), Pirinop, meu primeiro contato (Mari Corrêa e Kanaré Ikpeng, 2007), Martírio (Vincent Carelli, 2016) e Joaquim (Marcelo Gomes, 2017). Outros filmes serão acionados pontualmente.

\footnotetext{
${ }^{2}$ Segundo Koselleck (2006), o tempo histórico emerge da tensão entre espaço de experiência e horizonte de expectativa - categorias constitutivas da história e do seu conhecimento, ao entrelaçarem, na itinerância presente, o passado e o futuro. Entendemos historicidade como postula Hartog (2013): resultante dos "modos de articulação do passado, do presente e do futuro" (p. 28), sendo um dos componentes, a depender do momento histórico, do contexto e da experiência social, experimentado como dominante.
} 


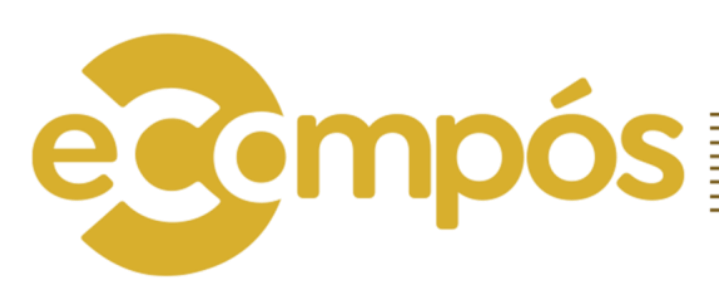

Da interação mais detida com algumas dessas obras, levantamos algumas hipóteses de trabalho. A primeira delas é de que se aposta no "presente como história" (GODARD; ISHAGHPOUR, 2000, p. 110). ${ }^{3}$ Pois o trabalho histórico não equivale, na maioria desses filmes, a uma representação do passado, mas envolve a atribuição de historicidade à atualidade. À diferença de "filmes históricos" tradicionais, que trabalham o passado per se, passível de reconstituição ou de representação, estes filmes o convocam para trabalhá-lo em sua relação com o presente (e, por vezes, com o futuro) de personagens, territórios e coletividades. São narrativas, em suma, que reabrem o passado no presente, para refletir e agir sobre a atualidade. Em algumas dessas obras, é justamente o trabalho de elaboração de tempos anteriores, impulsionado pelo fazer do filme no presente, que conduz a narrativa e o percurso do espectador.

Dessa constatação, desdobramos uma segunda hipótese: há presença expressiva, com modulações variadas nos filmes aqui reunidos, de "estéticas da elaboração". Esses filmes não se colocam como veículo de difusão de verdades prévias sobre o passado, mas sim como lugar de um trabalho (de investigação, rememoração, re-significação), necessariamente situado, parcial, em processo, marcado por pontos cegos e evasões. Tal processualidade não se restringe ao bastidor, mas é trazida ao primeiro plano, encaminhando a narrativa fílmica. Conduzidos no presente, processos de rememoração de violências sofridas pelos historicamente esquecidos, por exemplo, se abrem para as tensões, disputas e circunstâncias atuais. Interessa examinar, então, o duplo gume que cada obra nos oferece: entre a elaboração da narrativa fílmica e aquela da história coletiva.

\section{Cabra marcado para morrer: a "estética da elaboração" em perspectiva}

Por seu caráter paradigmático e inaugural, um verdadeiro "divisor de águas" no cinema brasileiro, como escreveu Bernardet (2003, p.9), iniciaremos nosso percurso por Cabra marcado para morrer, cuja abordagem nos permite lançar algumas premissas importantes, assim como colocar em perspectiva histórica a nossa problemática.

\footnotetext{
${ }^{3}$ Emprestamos com liberdade expressão proposta por Ishaghpour em sua discussão da história no cinema de Godard (GODARD; ISHAGHPOUR, 2000).
} 


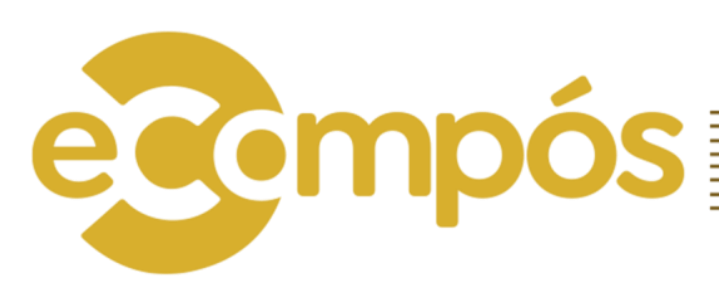

Iniciado em 1964, interrompido pelo golpe militar e retomado apenas em 1981, após a Anistia, o filme de Eduardo Coutinho, concluído finalmente em 1984, elabora uma "ponte" (BERNARDET, 2013, p. 227) entre a experiência histórica (e cinematográfica) no Brasil préditadura e aquela no limiar da redemocratização (início dos anos 1980). Dedica-se também a inscrever memórias de violências perpetradas durante o período ditatorial, resistindo ao esquecimento forçado. Na filmografia de Coutinho, Cabra inaugura uma dimensão diacrônica e um movimento de notável densidade: aquele caracterizado pela "preocupação em reconstruir o elo entre o passado e o presente de indivíduos e comunidades”, como escreveu Mateus Araújo Silva (2013, p. 433). Em outras palavras, um projeto peculiar de elaboração da história coletiva, reconhecida a ruptura (com os processos sociais então em curso) representada pelo golpe de 1964.

Como sugere Bernardet em seu artigo pioneiro (2003), ${ }^{4}$ tal projeto pode ser aproximado da concepção de história defendida por Walter Benjamin em suas teses (BENJAMIN, 1986). De fato, pensamos que caberia muito bem, para o cinema de Coutinho, a premissa benjaminiana de que "a relação entre hoje e ontem não é unilateral: em um processo eminentemente dialético, o presente ilumina o passado, e o passado iluminado torna-se uma força no presente", como sintetizou Löwy (2005, p. 61). É precisamente essa dinâmica de mútua inteligibilidade (entre experiência atual e passados rememorados), equacionada de modo singular por Cabra marcado para morrer, que nos interessa observar em nossa abordagem do cinema brasileiro contemporâneo.

Nesse sentido, o título em inglês do filme, Twenty years later (Vinte anos depois), é preciso. Em Cabra marcado, o intervalo de quase 20 anos entre as primeiras filmagens (interrompidas pelo golpe de 1964) e a retomada do filme é constitutivo, definidor de abordagem e narrativa. Quando Coutinho retorna ao Nordeste em busca dos participantes do filme, importa não apenas narrar a história da vida e do assassinato do líder camponês João Pedro Teixeira (que o filme de 1964 buscara reconstituir): é preciso elaborar, junto aos camponeses, em cena, mas também na montagem, esse hiato de quase duas décadas, de modo

\footnotetext{
${ }^{4}$ Vitória sobre a lata de lixo da história, publicado originalmente no suplemento Folhetim, do jornal Folha de São Paulo, em 1985. Republicado na segunda edição de Cineastas e imagens do povo (2003).
} 


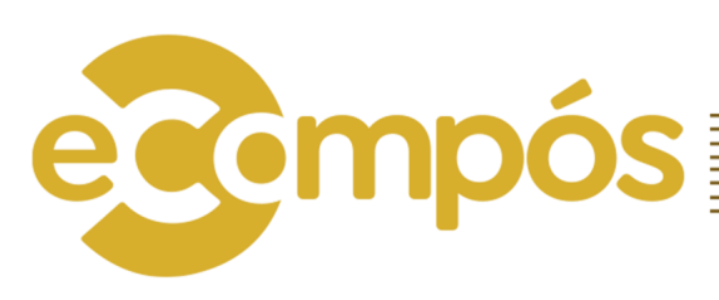

a construir uma passagem entre tempos, uma trilha que possa ser retomada no presente. $\mathrm{Na}$ primeira filmagem, se buscava fixar para a história - pela via de uma reconstituição ficcional uma imagem viva do presidente da Liga Camponesa de Sapé (PB), assassinado dois anos antes, por ordem de latifundiários. No segundo momento, passados 20 anos, o testemunho presente dos que sobreviveram à repressão militar torna-se o procedimento central. Trabalha-se a memória de João Pedro a partir de lembranças negociadas em cena, sob a sombra permanente do esquecimento (reforçado pela ditadura). O desafio de costurar, na montagem, essas matérias e fragmentos fílmicos heterogêneos, coincide com a tarefa de narrar a história, como se o processo-filme, abrigo de historicidade, correspondesse a um "cristal do acontecimento-total" (BENJAMIN, 2009, p.503): o golpe militar, a ditadura por ele instaurada e suas consequências para a sociedade brasileira (para os movimentos populares em específico).

Meditar sobre a história, na obra de Coutinho, é assim articular um "agora" e um "outrora", 5 reescrevendo do presente as histórias de lutas populares passadas, mas não remotas (há sobreviventes para contá-las). A atenção ao presente, tão importante para os filmes aqui reunidos, remonta a Cabra marcado para morrer: o filme é conduzido por reencontros atuais (entre cineasta e personagens), que deslancham a rememoração. Na história que interessa elaborar, confrontando o historicismo (cúmplice dos vencedores), "o passado pode ser compreendido somente à luz do presente”, como esclarece Löwy (2005, p.71), em sua leitura das teses de Benjamin. É o trabalho atual de rememoração que reabre o passado, dando uma nova chance ao que foi apagado ou encoberto (pela história oficial), mas também indagando o presente, colocando-o em perspectiva histórica, exigindo elaboração - como se as esperanças envolvidas nas lutas passadas viessem nos indagar sobre os rumos que a história lhes deu ou tem lhes dado. ${ }^{6}$

Neste ponto, podemos explicitar a proposta de articular "estéticas" e "elaboração" para caracterizar - a partir de diferentes modulações - o que realizam os filmes de nosso inventário (a começar por Cabra marcado para morrer, influente "divisor de águas" entre a produção documental moderna e contemporânea no Brasil). "Elaboração" remete ao trabalho de revisita ao passado (a episódios traumáticos e violentos, notadamente) - trabalho que se dá no

\footnotetext{
${ }^{5}$ Emprestamos sugestão de Mateus Araújo Silva em seu artigo "Straub, Huillet e o ensaísmo dos outros” (2013b). ${ }^{6}$ Para uma leitura minuciosa e esclarecedora das teses "Sobre o conceito de história", ver LÖWY (2005).
} 


\section{eccompós}

presente, e a ele se endereça. "Estéticas" concernem às modulações do "trabalho em ato" que essas obras compartilham com o espectador: nelas, o que se elabora aparece no passo da elaboração, tornada condução narrativa (sem a explicitação prévia, na maioria dos casos, de um tema central).

Assim como Cabra, muitos trabalhos contemporâneos fazem da filmagem ocasião de reabrir o passado no presente. Seja para sondar o que resta do passado entre nós; elaborar experiências traumáticas com a mediação do cinema; transmitir contra-versões da história; ou colocar o presente em perspectiva histórica, nele intervindo e buscando modificá-lo. Apresentamos, a seguir, as três figuras de elaboração que nortearão as séries de filmes contemporâneos propostas pelo artigo, de modo a encaminhar um mapeamento preliminar das formas pelas quais o cinema brasileiro tem abrigado "a tarefa de assumir a responsabilidade pelo passado" (HUYSSEN, 2014, p. 195): “um passado que não passa”; “o avesso do futuro” e "inventar para disputar memórias". 7

Importante destacar, de saída, que as fronteiras entre os conjuntos são porosas, e que múltiplas imbricações e contatos entre grupos de filmes poderiam ser estabelecidos. Mantemos a montagem de séries para fins exploratórios: diante da percepção da emergência crítica da rememoração no cinema brasileiro contemporâneo, e tendo montado um pequeno inventário, apostamos que a aproximação entre obras pode iluminar (pelo cotejo) suas características singulares, assim como extrair o que é recorrente nessa produção.

\section{Um passado que não passa: rememorar para historiar e agir no presente}

\footnotetext{
${ }^{7}$ Um quarto conjunto de filmes, centrado na performance (como procedimento de elaboração da experiência histórica) e em "fabulações críticas" da experiência negra, como tem sugerido Kênia Freitas (2018, 2019), poderia ser integrado ao nosso mapeamento atual (limitado pelo espaço disponível e pelas escolhas fílmicas). Pensamos em obras como Experimentando o vermelho em dilúvio (Michelle Mattiuzzi, 2016), Travessia (Safira Moreira, 2017), Pontes sobre abismos (Aline Motta, 2017), Noir Blue (Ana Pi, 2018) e A morte branca do feiticeiro negro (Rodrigo Ribeiro, 2019), entre outras, que investem nos diálogos com "os campos da performance e das artes visuais" (Freitas, 2019, p.1), na desmontagem de arquivos e/ou na presença do corpo em cena como espaço de ancestralidade e de "elaborações da história da diáspora negra" no presente, como nos diz André Brasil em seu artigo "Encruzilhadas, andarilhos, aprendizes: notas sobre três filmes performance" (2020). Em Noir Blue, para Kênia Freitas, o processo de fabulação deslanchado por Ana Pi apontaria "simultaneamente para uma memória ancestral dos gestos e das narrativas negras e para o processo especulativo de um futuro negro de liberdade expressiva plena" (2018, p. 117).
} 


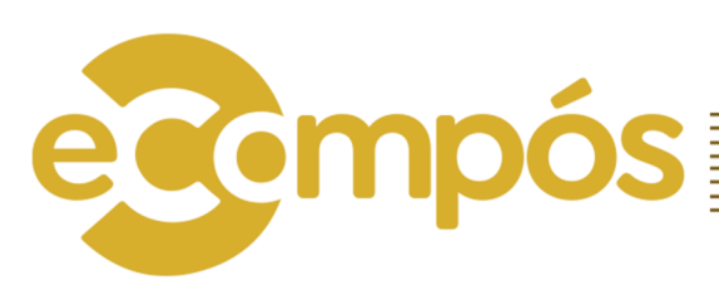

Abrangente, nossa primeira série reúne filmes que sugerem permanências do passado no presente. Elas são, grosso modo, mobilizadas como um "ataque do passado", na expressão de Huyssen $\left(2014\right.$, p. 177) ${ }^{8}$, às promessas de futuro envolvidas no discurso do progresso e nos projetos de modernização excludente, aliados do capital, que marcam a experiência social brasileira no tempo. Podem constituir ainda uma tática de abordagem crítica e de intervenção no presente, visando provocar alterações no curso de uma história de opressões.

A sugestão de permanência (do passado no presente) encontra amparo, como se sabe, na psicanálise: mais precisamente, no texto "Recordar, repetir e elaborar", de 1914, no qual Freud argumenta que conteúdos recalcados retornam sob a forma de repetições sintomáticas, caso não encontrem representação. Transportada para a abordagem de traumas sociais e históricos, como propõem Maria Rita Khel (2010) e Jeanne-Marie Gagnebin (2006), a discussão freudiana vem sugerir que os processos de rememoração e simbolização, de tornar públicas as violências e lutas que a história recalcou, participam da superação de uma experiência social marcada pela repetição sintomática da violência de Estado e pela tolerância com a impunidade. De diferentes maneiras, o cinema contemporâneo tem se voltado para memórias obscuras e negligenciadas, cujo recalque teria provocado, no presente, sintomas sociais. Assumida a tarefa da rememoração, encontramos variações nos modos como se elabora a sombra do passado sobre a atualidade. Indicamos a seguir algumas ênfases e variações a compor a série "Um passado que não passa".

A primeira delas reúne filmes que concedem maior espaço à ficção. São trabalhos que propõem dramaturgias realistas híbridas, em que a encenação ficcional convive com matéria documentária. O trânsito entre registros heterogêneos (encenações, arquivos e testemunhos) possibilita jogos de aproximação, distanciamento e comentários recíprocos (entre tempos passados e atualidade). É o caso de Acidade é uma só? (Adirley Queirós) e O som ao redor (Kleber Mendonça Filho), entre outros.

Em A cidade é uma só?, a operação histórica corresponde ao trabalho de aproximar arquivos visuais e sonoros (em sua maioria, registros "oficiais" do passado, propagandas e

\footnotetext{
${ }^{8}$ A expressão de Huyssen faz referência ao título do filme do cineasta alemão Alexander Kluge: "O ataque do presente contra o resto do tempo" (1985).
} 


\section{eccompós}

cinejornais referentes à história de Brasília) de dramatizações que envolvem as vivências de três personagens, moradores de Ceilândia, no presente (Dildu, Zé Bigode e Nancy). Também são fundamentais na elaboração contra-histórica que o filme propõe os testemunhos de Nancy, que reconta a história da CEI (Campanha de Erradicação de Invasões do Plano Piloto, que originou a Ceilândia em 1971), a partir de sua própria experiência (ainda criança, foi removida com a família do Plano Piloto). No trabalho de montagem, o discurso liso e utópico da propaganda governamental, que prometia a "cidade do futuro", é confrontado pelas vivências atuais e pelas memórias dos três protagonistas periféricos. A utopia modernista (que norteou o projeto de Brasília) é assim conduzida a sua contraface distópica: violência social, partilha desigual e segregação espacial são realidades na capital "do futuro" (50 anos depois de sua inauguração), mas também em episódios obscurecidos do passado (remontando à construção e ocupação de Brasília, agora de um ponto de vista radicalmente não oficial).

O jogo entre arquivos e encenações possibilita ainda a desnaturalização das vivências singulares dos protagonistas, expondo a historicidade do presente ao conectá-lo com a violenta história de um projeto nacional desenvolvimentista. Caso dos longos deslocamentos de ônibus de Dildu, que refaz cotidianamente o percurso Ceilândia-Plano Piloto para trabalhar - situação que a montagem sobrepõe, com ironia, em um dado momento, ao arquivo sonoro que se refere em tom grandiloquente à "épica aventura" de Brasília. Se confronta promessa de futuro (na propaganda) e vida presente, a operação também indica, nas vivências de um trabalhador, os efeitos da proletarização das periferias e da segregação histórica do espaço, induzidas pelo Estado na capital federal. ${ }^{9}$

Em $O$ som ao redor, elaborar a história é também trabalho de montar descontinuidades, arquivos (imagens do passado) e encenações (do presente). Mas, no filme de Kleber Mendonça Filho, a ficção é mais englobante, e as imagens de arquivo estão dispostas em uma única sequência à parte. Depois dos créditos iniciais, dez fotografias documentais compõem um painel abrangente da vida nos engenhos de cana da zona da mata pernambucana, nas primeiras

\footnotetext{
${ }^{9} \mathrm{O}$ arquivo sonoro é parte do cinejornal As primeiras imagens de Brasília (Jean Manzon, 1957). No trecho citado, a locução acompanha os planos feitos a partir de um avião sobrevoando as estradas que conectariam Brasília, em construção, ao restante do país. Desviada, a voz é remontada sobre a imagem atual do caminho entre Ceilândia e Plano Piloto - jornada "da segregação" (confinados os pobres no entorno periférico da cidade), como nos diz Tatiana Hora (2019).
} 


\section{eccompós}

décadas do século XX: da morada rústica de um trabalhador rural à casa grande; dos signos do poderio dos proprietários de terra (como o automóvel na porteira) às dezenas de trabalhadores organizados em liga, empunhando enxadas; do dia de festa ao trabalho no eito, do terreiro ao canavial. Após o prólogo, a ficção se incumbe de montar também, através das relações intersubjetivas postas em cena, um painel crítico de experiências e gestos sociais em um quarteirão de classe média alta na Recife atual. Posicionadas na abertura, as fotos documentais antecipam a sugestão - para toda a narrativa que se inicia - de que há permanências do passado rural, arcaico, agindo no espaço contemporâneo. Essa presença inquietante - trabalhada de diferentes maneiras no filme - ganha forma bem precisa no enredo, com a sugestão de uma vingança de morte, motivada pelo assassinato impune de um trabalhador (tramado pelo patriarca Francisco 30 anos antes, em seu engenho). Mas $O$ som ao redor nos instiga, pela maneira como trabalha as imagens de arquivo, a colocar todo o drama, todas as relações intersubjetivas (marcadas por desigualdades de classe e raça) em perspectiva histórica. $\mathrm{O}$ passado no engenho assombra não só o que "acontece" a alguns personagens, em suma, mas se projeta sobre toda a atualidade.

Mais híbrido em seu "laboratório" de formas fílmicas, Orestes também se move em torno da hipótese de permanência, no presente, de um passado que não passa. Como os demais, o filme de Rodrigo Siqueira assume, a seu modo, a tarefa de expor e elaborar danos e dilemas históricos constitutivos da experiência social no Brasil. Nele, o que fundamenta a relação (entre passado e presente, e mais precisamente, entre período da ditadura e atualidade) é a violência de Estado, a continuidade de práticas abusivas (pelos poderes públicos) de que são ou foram vítimas (direta ou indiretamente) parte significativa dos personagens no filme. Mas Orestes mobiliza uma série mais heterogênea de procedimentos: da investigação documentária à simulação de um tribunal (em diálogo com a Oréstia, trilogia trágica de Ésquilo), passando por um experimento de "elaboração em ato": o convite a algumas pessoas, que não se conhecem, para que interajam em dois espaços desativados (o DOI-CODI e o teatro TAIB, em São Paulo), participando de dinâmicas psicodramáticas propostas pela equipe. Agenciando o encontro, entre outros, de uma filha de desaparecidos políticos durante a ditadura e de pais de vítimas da polícia no Brasil de hoje (jovens negros e periféricos, sobretudo), o filme parece tacitamente 


\section{eccompós}

indagar: "O que resta, entre nós, da ditadura?"10 O dispositivo fílmico encaminha sugestões: processos incompletos ou impossibilitados de luto, sintomas sociais, irresoluções históricas.

Também se valendo de encenações, mas atravessadas por forças documentárias, outro grupo de filmes privilegia a retomada de episódios do passado pelos protagonistas reais da história. A tática não é acionada como forma de reposição ou reconstituição do vivido como fato, mas estabelece uma ocasião presente para sua elaboração, como propõe Clarisse Alvarenga (2017). ${ }^{11}$ Nesse sentido, a reencenação cria outras experiências - até porque aqueles que reencenam não são mais os mesmos, modificados pelo tempo. Diferente da reconstituição, que postula a autonomia da cena ficcional que repõe o passado, a reencenação promove "uma aproximação entre temporalidades distintas" (ALVARENGA, 2017, p. 84), aliando-se ao testemunho em cenas porosas aos atravessamentos e tensões atuais. Pensemos em filmes como Serras da desordem (Andrea Tonacci) e Pirinop, meu primeiro contato (Mari Corrêa e Kanaré Ikpeng), que envolvem a elaboração presente de traumas coletivos sofridos por grupos indígenas em um passado recente: neles, presente e passado se emaranham nos espaços revisitados e nos corpos dos atores-personagens (indígenas que sobreviveram aos massacres e deslocamentos forçados sofridos por seus povos). Sendo assim, o passado assoma em cena antes como presença do que como legado, ferida aberta que deixa marcas e se atualiza nos gestos, palavras e não-ditos dos atores, podendo também ser estrategicamente retomado em contraversões da história e disputas atuais.

Pensemos em Pirinop, meu primeiro contato: motivados pelo fazer do filme, em 2006, quando se propôs a exibição, na aldeia, de imagens de arquivo que registram o primeiro contato (realizadas por Jesco Von Puttkamer, cinegrafista que participava da expedição comandada pelos Irmãos Villas-Boas), os Ikpeng reencenam, de sua perspectiva, o encontro com os brancos em 1964. A reencenação é aberta aos comentários presentes da comunidade, sendo repensada a partir do feedback do material filmado, exibido à noite para toda a aldeia. Assim, contrariamente à ambição de restituir intacta uma imagem do passado (que ignorasse todas as

\footnotetext{
${ }^{10}$ Fazemos aqui referência ao livro organizado por Edson Telles e Vladimir Safatle: $O$ que resta da ditadura: a exceção brasileira (2010).

${ }^{11} \mathrm{Em}$ seu livro Da cena do contato ao inacabamento da história, a autora trabalha com filmes-processo que retomam imagens do contato com povos isolados no Brasil: Os últimos isolados (1967-1999), Corumbiara (19862009) e Os Arara (1980-).
} 


\section{eccompós}

transformações vividas em quatro décadas de contato), o processo de reencenar também sonda e coloca em perspectiva histórica o próprio presente ("você falou português", "tem que fazer de novo sem a roupa": são alguns dos comentários críticos ouvidos durante a projeção coletiva do material bruto). Rememorar para intervir em um presente em luta: "nesse processo", como escreve Clarisse Alvarenga, "emerge no grupo uma nova orientação em relação ao seu futuro: eles pretendem retomar as terras onde viviam quando foram contatados e das quais estiveram afastados desde a transferência para o Parque Nacional do Xingu, ocorrida após o primeiro contato" $\left(2017\right.$, p.85). ${ }^{12}$

Um terceiro grupo, com documentários que não acionam táticas ficcionais e reencenações, trabalha a montagem de materiais heterogêneos, sobretudo arquivos (de variadas procedências) e intervenções (da equipe de cinema) em situações atuais. Nesse caso, articulase a narrativa (da história) com a participação ou intervenção (em seu curso conflituoso, que se atualiza). É o caso exemplar de Corumbiara e Martírio (Vincent Carelli), que articulam, como nos mostra André Brasil (2016), um trabalho de militância, vivência e urgência junto a grupos indígenas ameaçados por projetos de colonização e pela expansão capitalista, com um gesto reflexivo, rememorativo, debruçado sobre ampla matéria histórica, "tornando indissociáveis esses gestos, sem os quais a experiência histórica não se constitui enquanto tal” (BRASIL, 2016, p. 150). Pois a atualidade do genocídio dos Guarani Kaiowá parece exigir, a um só tempo, a ação e a memória (como se vê em Martírio): a colocação em perspectiva histórica de um processo de extermínio, expropriações e esbulhos territoriais se articula à urgência de intervir, com o cinema, em seu curso presente. Nesse sentido, chama atenção a sequência final do filme, em que os pistoleiros que atacavam a retomada kaiowá de Pyelito são flagrados pelas câmeras deixadas pela equipe de cinema com os moradores da comunidade. Imagens que se tornam provas, que concretizam e atualizam a crueldade histórica do entorno branco contra os Guarani Kaiowá.

\footnotetext{
${ }^{12} \mathrm{~A}$ potência da (re)encenação para produzir, no presente, "imagens que faltam" (quando não há arquivos registrados da perspectiva dos indígenas que foram vítimas da violência de projetos de expansão e colonização) também se mostra em Ava Yvy Vera, produzido por um coletivo de jovens e lideranças Guarani Kaiowá da retomada Guaiviry. André Brasil o comenta em "Rumo à terra do povo do raio: retomada das imagens, retomada pelas imagens em Martírio e Ava Yvy Vera" (2020).
} 


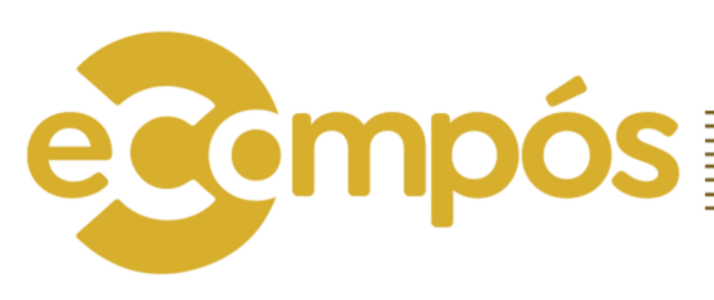

\section{O avesso do futuro: memória e distopia}

Nossa segunda série privilegia filmes que apresentam construções temporais ainda mais intrincadas. Elas incluem a encenação de presentes incertos e a especulação de "futuros", veículo para figurações distópicas em que a experiência social recebe tons sombrios, por vezes pós-apocalípticos. O isolamento espacial, social e político marca os modos como alguns personagens aparecem em cena, maquinando revoltas, vinganças, intrusões, sem horizonte utópico. Na filmografia de Adirley Queirós e em outros trabalhos recentes, testemunhos e outros traços documentais convivem com desvios pela ficção, incluídos diálogos com gêneros industriais. Resultam dramaturgias realistas híbridas, empenhadas em figurar aspectos precários da experiência social em grandes cidades brasileiras, como a segregação espacial, a falência da vida em comum e a obsolescência precoce de pessoas e territórios.

Tal emergência da distopia como "ferramenta de análise radical" do presente (HILÁRIO, 2013), bem como do caráter injusto de nossa formação social, já se fazia sentir, de maneira irônica e bem-humorada, em Recife Frio (2010), curta de Kleber Mendonça Filho. O letreiro inicial ("daqui a alguns anos") sinaliza o híbrido de falso documentário e filme de ficção científica, no qual a especulação de um futuro misteriosamente frio (em uma das cidades mais quentes do Brasil), acessado pelo espectador através de uma falsa reportagem de TV, alcança ao menos dois efeitos: expor as contradições sociais e aporias urbanas de uma Recife bem presente; ironizar códigos e convenções da forma documental trivializada na televisão.

Mesmo que muito diferentes entre si, longas mais recentes - como Branco sai, preto fica e Era uma vez Brasília (Adirley Queirós, 2014 e 2017), Batguano (Tavinho Teixeira, 2014), Medo do escuro (Ivo Lopes Araújo, 2015) e Tremor Iê (Elena Meirelles, Lívia de Paula, 2019) - também apresentam construções temporais intrincadas, nas quais o "presente" oscila entre uma atualidade reconhecível e um futuro especulado, e o passado comparece sob a forma de ruínas e memórias traumáticas, objetos técnicos obsoletos e resíduos presentes nos espaços urbanos postos em cena ("não-lugares de memória" marcados mais pelo apagamento e pela obsolescência precoce do que por uma conservação refletida e programada do passado). Entre um passado que não passa e o avesso do futuro (tal como prometido pelos processos de 


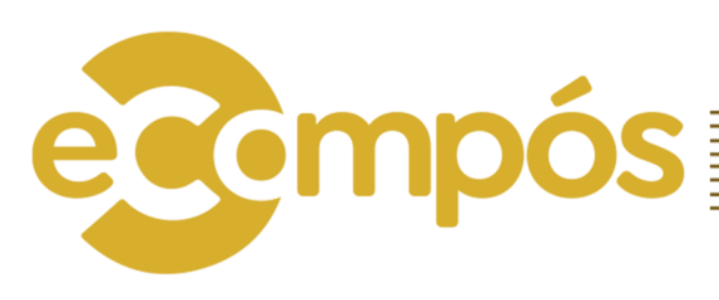

modernização capitalista), a atualidade de grandes cidades brasileiras é trabalhada de modo a expor danos, precarização, exclusões.

Entendemos que, se a confiança moderna no futuro está na base das utopias literárias e políticas, as narrativas distópicas dão forma ao assombro com o presente, buscando indicar “catástrofes que se perfilam no horizonte” (LÖWY, 2005, p.32). Nas obras reunidas em nossa segunda série, especulações de futuro e outros desvios pela ficção são mobilizados, por vezes, como resposta crítica a experiências históricas bem precisas. É o caso dos filmes de Adirley Queirós, que - a começar por A cidade é uma só? - retomam o planejamento, a construção e a paradoxal ocupação de Brasília, inaugurada em1960. Contrariando a estética do apagamento, a ruptura com o passado e a proposta descontextualizante do projeto modernista de Brasília (HOLSTON, 1993), o cinema de Queirós se volta para a rememoração do passado recente, privilegiando o ponto de vista de quem habita a periferia (da cidade e da história). No lugar de documentários históricos tradicionais, contudo, operam-se surpreendentes desvios pela ficção, que ora se torna abrigo de testemunhos e arquivos, ora abre espaço para reinvenções do presente e especulações distópicas (incluídos diálogos com gêneros industriais).

Branco sai, preto fica (2014) é, nesse sentido, paradigmático. Para abordar um acontecimento real passado, sucedido em Ceilândia (DF), o filme faz um desvio pela ficção científica, que se torna abrigo de rememorações e espaço para invenção deliberada de um futuro coletivo. Do ano 2070, aterrissa na atualidade de Brasília o agente Dimas Cravalanças, viajante no tempo incumbido de colher evidências de crimes cometidos pelo Estado contra populações negras e periféricas. Os atores Marquim do Tropa e Shokito emprestam seus corpos e memórias aos protagonistas Marquim e Sartana, que no filme ruminam suas perdas (ambos mutilados pela repressão policial a um baile black em Ceilândia) e gestam um plano terrorista de ação. Passagem entre um futuro ficcional utópico, tratado com ironia, no qual a dívida do Estado brasileiro para com os negros e pobres seria literalmente paga, e um passado real traumático, em que - ao contrário - eles tiveram sua presença na cidade mutilada pelo mesmo Estado, situase o tempo dominante na narrativa: o "presente" de Ceilândia. Entre aspas: a atualidade já 


\section{eccompós}

aparece especulada pela ficção, que extrapola características da ordem social e urbana de Brasília, de modo a tornar mais nítido o desenho distópico. ${ }^{13}$

$\mathrm{Na}$ origem da ficção, portanto, um episódio vivido: a repressão policial ao baile Quarentão, que feriu e mutilou jovens negros em 1986. Ele é tomado como paradigma da opressão continuada às populações periféricas em Brasília, expostas cotidianamente à violência arbitrária do Estado. Nesse sentido, a encenação se empenha em figurar o presente, na contramão da promessa utópica, como terra arrasada: quando aparece nas andanças de Cravalanças, Ceilândia é composta de espaços baldios, ermos, semiabandonados; já os modos de aparição de Marquim e Sartana, quase sempre solitários, sugerem o recolhimento da vida na cidade, vista do alto ou distanciada. Trabalhando a duração nos espaços interiores dos protagonistas, marcados por improvisos e bricolagens, a construção fílmica do tempo faz pensar na temporalidade melancólica (KRISTEVA, 1989): um tempo descentrado, que não "se escoa bem", como se toda a Ceilândia estivesse "pausada", marcada pelo trauma e pelas rememorações de Marquim e Sartana.

Era uma vez Brasília (2017) prolonga os experimentos temporais dos filmes anteriores, também elaborando o presente como "avesso do futuro" (sob a sombra de um "passado que não passa"). Novamente Adirley responde ao projeto futurista que norteou a construção da capital brasileira com a criação de um presente distópico: o setor habitacional Sol Nascente, expansão da Ceilândia, neste filme inteiramente noturno, oferece locações para a "cidade do futuro" (e empresta, na dramaturgia, o nome ao "planeta" de onde parte WA, viajante intergaláctico). Os espaços internos são densamente elaborados: a nave espacial de WA, o viajante que incumbido de eliminar Juscelino Kubitscheck - se perde no tempo e no espaço e cai na Ceilândia em 2016, é precária e insalubre como uma cela de prisão brasileira. Já presente em Branco sai, preto fica, ganha força a aposta na construção cênica, na performance dos atores nos espaços, registrada em sua duração. Constrói-se assim uma atmosfera de imobilidade, isolamento e confinamento - em uma espécie de "cifra" da condição precária e periférica,

\footnotetext{
${ }^{13}$ Em sua leitura do filme (2015), Kênia Freitas se vale da noção de afrofuturismo, formulada por Mark Dery para "tratar das criações artísticas que por meio da ficção científica inventam outros futuros para as populações negras atuais": Se "as narrativas de ficção científicas são formas especulativas de pensar o presente", argumenta a autora, Branco Sai Preto Fica pode ser pensado "como uma exploração afrofuturista do dia a dia da população negra brasileira" (2015, p.1).
} 


\section{eccompós}

elaborada nas imagens, de modo mais alegórico. Se a temporalidade é complexa, a referência ao passado tornou-se menos precisa, menos "documentária": é como se a distopia estivesse de tal modo instalada que não fosse mais possível remontar sua história.

Não sendo a rememoração tão decisiva, a referência a processos políticos atuais é mobilizada de modo direto e contundente: a montagem sobrepõe às imagens da ficção registros sonoros de discursos e declarações de voto, referentes ao processo do impeachment da presidente Dilma Rousseff. ${ }^{14}$ Se um filme como A cidade é uma só? produz uma contramemória que confronta o apagamento e o recalque do violento processo de retirada dos pobres do Plano Piloto em tempos passados, Era uma vez Brasília parece sondar um recalcamento em ato: sobreposto às imagens sombrias do presente narrativo (especulado em chave distópica), o discurso de posse de Temer, no final do filme, é a mais acabada expressão da denegação e do mascaramento (coroando todas as manipulações, distorções e a amnésia programada que cercaram o golpe de Estado). ${ }^{15}$

Na continuidade da relação traumatizante e violenta do Estado com os moradores das periferias, o passado ainda assombra um presente avesso a toda idealização (como nos filmes reunidos na primeira série): lugar, na filmografia de Adirley Queirós, de confronto radical das promessas utópicas de futuro na base do projeto político, arquitetônico e urbanístico de Brasília.

\section{Encenar para disputar memórias: ficções meta-históricas}

Por conduzir a "estética da elaboração" a variações mais incisivas, uma terceira frente, oferecida pelos filmes "históricos" em sentido estrito, será apenas introduzida no presente artigo: referimo-nos às ficções que reconstituem o passado. Partimos do pressuposto que mesmo filmes que se atêm a reencenar episódios vividos (sem relacioná-los, na montagem, a outros tempos) podem trazer inscrita em suas escolhas uma reflexão atual. Apostamos que as melhores reconstituições revelam “o vórtice dos conflitos atuais” (HUYSSEN, 2014, p. 192),

\footnotetext{
${ }^{14}$ Ouvimos discursos de Dilma, de Temer, de parte da bancada do Paraná na votação do impeachment na Câmara dos Deputados. Há também um trecho do discurso de JK na cerimônia de inauguração de Brasília, em 1960.

${ }^{15}$ Um trecho do discurso de Temer: "O momento é de esperança na retomada do Brasil. A incerteza chegou ao fim. É hora de unir o país e colocar os interesses nacionais acima dos interesses de grupos. (...) Tudo transcorreu dentro do mais absoluto respeito constitucional. Demos esse exemplo ao mundo."
} 


\section{eccompós}

conduzindo, por vezes, a uma história de segundo grau - seja porque não têm em conta apenas o acontecimento passado, mas suas formas de representação no tempo; seja porque se endereçam criticamente à administração ou gestão da memória pública pelos poderes, ontem e hoje. Interessam-nos, assim, as formas pelas quais as encenações e reconstituições ficcionais, ao representarem tempos passados, realizam construtos meta-históricos ou se endereçam ao nosso presente.

Joaquim, de Marcelo Gomes, combina invenção dramatúrgica (na escolha por abordar um período inteiramente desconhecido e não-documentado da vida de Tiradentes) e realismo histórico (no rigor da pesquisa que fundamenta suas escolhas de encenação). O prólogo do filme evidencia a consciência meta-histórica e o endereçamento crítico da proposta. Sobre a imagem (em plano geral fixo) de uma cabeça humana exposta sob chuva, ouvimos a fala póstuma de Tiradentes, que remete a Brás Cubas (personagem de Machado de Assis): “Aqui quem vos fala é um decapitado (...) Outros homens também conspiraram contra a Coroa portuguesa, mas apenas eu perdi a cabeça. Talvez por ser mais pobre, talvez por ser mais exaltado". As gotas que caem na lente da câmera sinalizam a rememoração dos antecedentes da Inconfidência Mineira, no século XVIII, como projeto fílmico deliberadamente atual. O modo como se constrói a subjetividade e a motivação para a revolta de Tiradentes (marcadas por experiências, ressentimentos e frustrações de classe) as contrasta com aquelas dos demais inconfidentes, bem mais privilegiados do que ele (como o filme cifra, de maneira sintética, em sua última cena, quando Tiradentes é objeto de censura e escândalo, ao almoçar pela primeira vez com todo o grupo). Motivo que sinaliza, a nosso ver, a possibilidade de leitura alegórica: como se o passado reencenado prefigurasse o nosso presente, ou tivesse algo a nos dizer sobre os processos políticos em curso no momento de realização do filme. ${ }^{16}$

Assim, em seu endereçamento presente, Joaquim parece preocupado não apenas em situar, mas em colocar em perspectiva a visão de mundo (e mesmo o lugar de fala) de

\footnotetext{
${ }^{16}$ Pensamos, especificamente, no fenômeno do antipetismo, no golpe contra Dilma Rousseff e na sanha de parte das elites brasileiras em destruir a história de Luiz Inácio Lula da Silva (um operário que chegou à presidência do país). Embora em chave distinta, a sugestão alegórica e a construção meta-histórica nos remetem a $O s$ inconfidentes, realizado no período dito "moderno" do cinema brasileiro. Em momento de endurecimento do regime militar (1972), o filme de Joaquim Pedro de Andrade recapitula os tempos da Inconfidência Mineira (17891792), não só para disputar a memória coletiva da revolta, intensamente apropriada pelos poderes, como para refletir - com alguma liberdade crítica - sobre aspectos de um presente doloroso e sombrio.
} 


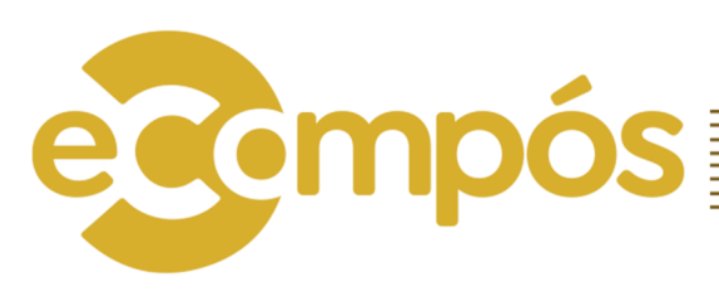

Tiradentes. Por um lado, seu ponto de vista é contrastado àquele dos demais inconfidentes cujo horizonte de classe é bem distinto do dele. Por outro lado, importa também contrastar a experiência de um homem branco livre às "outras humanidades" que personagens indígenas e negros encarnam em cena. O que se nota no encontro entre Inhambupé, indígena, e João, negro escravizado, que participam da expedição de busca de ouro no sertão, comandada por Joaquim. No amanhecer de um dia, os dois compartilham rezas e louvações, colocando em contato línguas, cantos, espiritualidades. Sugere-se na cena todo um extracampo: a agência de diferentes cosmologias que resistem e amparam esses sujeitos (apesar da extrema violência que sofreram, arrancados de seus povos e territórios pelo projeto colonial). Já Tiradentes, obcecado por ouro como os colonizadores que o oprimem, subjetivamente transtornado, ao fitar na mesma cena um espelho d'água, não consegue enxergar nada mais do que a imagem de sua própria desfiguração.

Em nosso inventário da produção contemporânea, filmes como Joaquim nos fazem rever alguns dos trabalhos comentados nas séries anteriores, com ênfase na elaboração de uma "história de segundo grau". Obras que têm em conta não apenas o acontecimento passado, mas suas formas de registro, as apropriações e perpetuações da memória coletiva no tempo (aspectos presentes, por exemplo, em A cidade é uma só?). Filmes que, ao mobilizarem uma escrita do passado, disputam, em suma, memórias no presente. Assim, as pontas de nosso inventário se encontram.

\section{Considerações finais}

Com suas elaborações singulares, os filmes reunidos nas três séries aqui propostas compartilham um esforço comum: a criação de formas que elaborem o passado histórico não como legado, mas como presença, ferida, sintoma atual. Na contramão das representações apaziguadas ou idealizantes de tempos pretéritos, preferem sugerir os danos históricos presentes entre nós, desnaturalizando a atualidade ou fazendo da disputa de memórias um instrumento para intervenção no curso conflituoso e violento de uma história que se atualiza.

A “emergência de novos discursos memoriais" (HUYSSEN, 2014, p. 95) não apenas se associa, no cinema brasileiro contemporâneo, ao colapso das energias utópicas, como parece se 


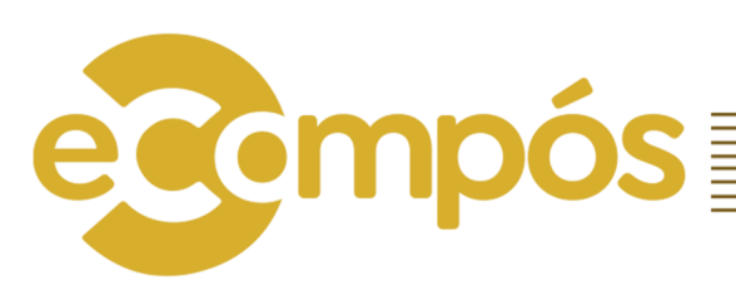

voltar, insistentemente, ao presente: lugar de irresolução, incompletude e inacabamento, características internalizadas pelas narrativas fílmicas em seus "processos" ou "estéticas" da elaboração. Sob a sombra de um passado (que não passa), na contramão das promessas de futuro, eis o presente: tempo de um trabalho (parcial, situado) de elaboração histórica, propulsionado pelo filme em seu fazer.

Sem dúvida, muitos contatos e vizinhanças poderiam ser estabelecidos entre as séries aqui propostas, e no interior delas - alguns estão sugeridos no percurso deste artigo. Eles revelam, por um lado, a recorrência da associação entre rememoração crítica e falência dos discursos modernizantes e progressistas. Movidos por urgências e aporias do presente, os filmes se fincam na atualidade, elaborada como um híbrido de temporalidades. Está no horizonte das três séries, portanto, "o presente como história” (GODARD; ISHAGHPOUR,2000, p. 110). Por isso parece-nos pertinente a retomada de Cabra marcado para morrer, filme paradigmático, que se volta para o passado (a rememoração das lutas camponesas e da repressão sofrida após o golpe de 1964), movido pelas urgências que se apresentavam no limiar da redemocratização. Como o filme de Coutinho, as obras aqui reunidas trabalham (de diferentes maneiras) dinâmicas que confrontam tempos, que promovem indagações recíprocas entre presente e passados.

Contudo, diferentemente de Cabra marcado, cujo final é esperançoso, abrindo-se para um novo tempo da sociedade brasileira, nosso inventário de formas críticas aponta, na trilha de Huyssen (2014), para o enlace entre a força da rememoração e o esvaziamento das energias utópicas na contemporaneidade. Se a imaginação de futuros melhores parece vetada para nós, o presente não está encerrado: lugar de disputa, de trabalho, de processos que participam da história, ao buscarem elaborá-la.

\section{Referências}

AB'SÁBER, Tales. Cabra marcado para morrer, cinema e democracia. In: OHATA, Milton (Org.). Eduardo Coutinho. São Paulo: Cosac Naify, 2013, p. 505-522.

Ordem e violência no Brasil. In: KUCINSKY, Bernardo (Org.).Bala perdida: a violência policial no Brasil e os desafios para sua superação. São Paulo: Boitempo, 2015, pp.97-102. 


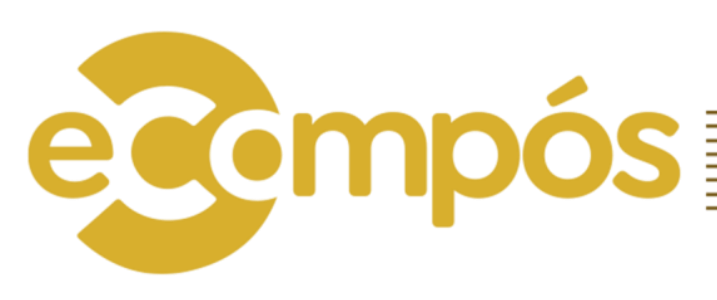

ALVARENGA, Clarisse. Da cena do contato ao inacabamento da história: Os últimos isolados (1967-1999), Corumbiara (1986-2009), Os Arara (1980-). Salvador: EDUFBA, 2017.

BENJAMIN, Walter. Magia e técnica, arte e política. São Paulo: Brasiliense, 1986.

Passagens. Belo Horizonte: Editora UFMG, 2009.

BERNARDET, Jean-Claude. Cineastas e imagens do povo. São Paulo: Cia. das Letras, 2003.

BRASIL, André. Encruzilhadas, andarilhos, aprendizes - sobre três filmes-performance. Significação - Revista de Cultura Audiovisual. São Paulo, v. 47, n. 53, p. 21-47, jan./jun. 2020 .

Retomada: teses sobre o conceito de história. In: TORRES, Júnia et al. (Org.)

Catálogo doforumdoc.bh 2016. Belo Horizonte: Associação Filmes de Quintal, 2016.

Rumo à terra do povo do raio: retomada das imagens, retomada pelas imagens em Martírio e Ava Yvy Vera.In: BRASIL, A.; FURTADO, B.; PARENTE, A. Imagem e exercício da liberdade: cinema, fotografia e artes - imagem contemporânea III. Fortaleza: Imprensa Universitária UFC, 2020.

FREITAS, Kênia; BARROS, Laan. Experiência estética, alteridade e fabulação no cinema negro. Revista ECO Pós. Dossiê Racismo. Rio de Janeiro, v. 21, n. 3, p. 97-121, 2018.

Fabulações críticas em curta-metragens negros brasileiros. Multiplot! - revista eletrônica de crítica de cinema, 2019. Disponível em:

http://multiplotcinema.com.br/2019/03/fabulacoes-criticas-em-curta-metragens-negrosbrasileiros/.

Branco Sai Preto Fica (Adirley Queirós, 2014). Multiplot! - revista eletrônica de crítica de cinema, 2015. Disponível em: http://multiplotcinema.com.br/2015/04/branco-saipreto-fica-adirley-queiros-2014/.

GAGNEBIN, Jeanne-Marie. Memória, história, testemunho. In: Lembrar, escrever, esquecer. São Paulo: Editora 34, 2006.

GODARD, J-L.; ISHAGHPOUR, Y. Archéologie du cinéma et mémoire du siècle (dialogue). Tours: Farrago,2000.

HARTOG, François. Regimes de historicidade. Presentismo e experiências do tempo. Belo Horizonte: Editora Autêntica, 2013.

HOLSTON, James. A cidade modernista: uma crítica de Brasília e sua utopia. São Paulo: Companhia das Letras, 1993. 


\section{eccompós}

HORA, Tatiana. Utopias de Brasília no cinema: o desvio contra a arquitetura e a história. 2019. Tese (Doutorado em Comunicação Social). UFMG. Belo Horizonte, 2019.

HUYSSEN, Andreas. Culturas do passado-presente: modernismos, artes visuais, políticas da memória. Rio de Janeiro: Contraponto, 2014.

KEHL, Maria Rita. Tortura e sintoma social. In: SAFATLE, Vladimir; TELES, Edson (Org.). O que restada ditadura: a exceção brasileira. São Paulo: Boitempo, 2010.

KOSELLECK, Reinhart. Futuro passado: contribuição à semântica dos tempos históricos. Rio de Janeiro:Contraponto, 2006.

KRISTEVA, Julia. Sol negro - depressão e melancolia. Rio de Janeiro: Rocco, 1989.

LÖWY, Michael. Walter Benjamin: aviso de incêndio - uma leitura das teses "Sobre o conceito dehistória". São Paulo: Boitempo, 2005.

NORA, Pierre. Entre memória e história: a problemática dos lugares. Proj. História, São Paulo, PUC-SP, n. 10, p. 7-28, dez.1993. Disponível em:

http://revistas.pucsp.br/index.php/revph/article/viewFile/12101/8763

SELIGMANN-SILVA, Marcio. O local do testemunho. Tempo e argumento. Revista do Programa de Pós-Graduação em História, Florianópolis, v.2, n.1, p. 3-20, jan./jun. 2010.

SILVA, Mateus Araújo. Eduardo Coutinho, Pierre Perrault e as prosódias do mundo. In: OHATA, Milton (Org.). Eduardo Coutinho. São Paulo: CosacNaify, 2013, p. 432-439.

Straub, Huillet e o ensaísmo dos outros. Devires- Cinema e Humanidades, Belo Horizonte, v. 10, n. 1, p. 108-137, jan./jun. 2013b.

\section{Filmografia}

A CIDADE É UMA SÓ? Direção: Adirley Queirós. Produtora: Ceicine. Brasil, 2012. 1 DVD (79 min).

BRANCO SAI, PRETO FICA. Direção: Adirley Queirós. Produtora: Ceicine. Brasil, 2014. 1 DVD (93 min).

CABRA MARCADO PARA MORRER. Direção: Eduardo Coutinho. Produtora: Mapa Filmes. Brasil, 1984. 1 DVD (120 min).

CORUMBIARA. Direção: Vincent Carelli. Produtora: Vídeo nas Aldeias. Brasil, 2009. 1 DVD (117 min).

ERA UMA VEZ BRASÍLIA. Direção: Adirley Queirós. Produtora: Ceicine. Brasil, 2017. 1 DVD (100 min).

JOAQUIM. Direção: Marcelo Gomes. Produtora: REC. Brasil, 2017. 1 DVD (102 min). MARTÍRIO. Direção: Vincent Carelli, Ernesto de Carvalho e Tita. Produtora: Vídeo nas Aldeias. Brasil, 2016. 1 DVD (162 min). 


\section{eccompós}

O SOM AO REDOR. Direção: Kleber Mendonça Filho. Produtora: Cinemascópio. Brasil, 2012. 1 DVD (131 min).

ORESTES. Direção: Rodrigo Siqueira. Produtora: 7Estrelo. Brasil, 2015. 1 DVD (93 min).

OS INCONFIDENTES. Direção: Joaquim Pedro de Andrade. Produtora: Filmes do Serro.

Brasil, 1972. 1 DVD (100 min).

PIRINOP, MEU PRIMEIRO CONTATO. Direção: Mari Corrêa e Kanaré Ikpeng. Produtora: Mari Corrêa. Brasil, 2007. 1 DVD (83 min).

RECIFE FRIO. Direção: Kleber Mendonça Filho. Produtora: Cinemascópio. Brasil, 2010. 1 DVD (25 min).

SERRAS DA DESORDEM. Direção: Andrea Tonacci. Produtora: Extremart. Brasil, 2006. 1

DVD (130 min).

\section{Claudia Mesquita}

Doutora em Ciências da Comunicação pelo Programa de Pós-Graduação em Comunicação da Escola de Comunicação e Artes da Universidade de São Paulo. Professora do Departamento de Comunicação Social e do Programa de Pós-Graduação em Comunicação da Universidade Federal de Minas Gerais.

Universidade Federal de Minas Gerais, Belo Horizonte, Minas Gerais, Brasil

E-mail: claudmesq@gmail.com

ORCID: https://orcid.org/0000-0003-1983-0963

\section{INFORMAÇÕES SOBRE O ARTIGO}

Resultado de projeto de pesquisa: o artigo é resultado da pesquisa de pós-doutorado " $\mathrm{O}$ presente como história: estéticas da elaboração no cinema brasileiro contemporâneo" (Universidade Federal do Ceará, 2018-2019).

Fontes de financiamento: não se aplica.

Considerações éticas: não se aplica.

Declaração de conflito de interesses: não se aplica.

Apresentação anterior: $27^{\circ}$ Encontro anual da Compós, 2018, Belo Horizonte.

Agradecimentos/Contribuições adicionais: aos participantes do GT Estudos de Cinema, Fotografia e Audiovisual do $27^{\circ}$ Encontro anual da Compós, onde uma primeira versão do artigo foi debatida, em especial a Angela Prysthon, que o relatou. A Beatriz Furtado (UFC), supervisora da pesquisa de pós doc, por seu apoio e interlocução. 